\title{
The Impact of COVID -19 to the Malaysian Social-Economic and Islamic Banks, and the Role of Maqasid Shariah
}

\author{
Siti Noradibah Md Zain \\ Faculty of Economics and Muamalat, Universiti Sains Islam Malaysia (USIM), \\ Bandar Baru Nilai, 71800 Nilai, Negeri Sembilan Malaysia \\ E-mail: noradiba_zyn@yahoo.com \\ Norhazlina Ibrahim (Corresponding author) \\ Faculty of Economics and Muamalat, Universiti Sains Islam Malaysia (USIM), \\ Bandar Baru Nilai, 71800 Nilai, Negeri Sembilan Malaysia \\ E-mail: norhazlina@usim.edu.my
}

Received: Jan. 24, 2022 Accepted: Feb. 28, 2022 Published: March 6, 2022

doi:10.5296/ijssr.v10i1.19499 URL: https://doi.org/10.5296/ijssr.v10i1.19499

\begin{abstract}
The COVID-19 outbreak is a global health issue that has hit countries around the globe. This pandemic has further been detrimental to the world's socio-economies. The many restrictions implemented to curb the spread of the virus, such as the Movement Control Order (MCO), have resulted in socio-economic constraints that harm the commercial activities of individual businesses as well as corporate organisations. The MCO has also been alleged to negatively affect people's mental health due to its impact on decreasing household income and exacerbating poverty. The banking sector is not immune to the pandemic's effect, as reflected in its financial performance. As a result, the Malaysian government responded by announcing stimulus packages for businesses and retail sectors. At the same time, the financial institution through the Bank Negara Malaysia (BNM) remains committed to helping households and businesses. Thus, this paper aims to discuss the impact of COVID-19 on the performance of Islamic banking institutions from a socio-economic lens by comparing the first and second-quarter profits of the years 2019 and 2020. This study also looks into the roles of Maqasid Shariah and its application during the pandemic. Content analysis was applied as a
\end{abstract}




\section{Macrothink}

tool for data collection from related websites, news and quarterly financial reports to analyse the performance of the banks. Analysis of the quarterly financial reports found that bank profit demonstrated a steep decline during the second quarter of the said period, constant with the middle of the MCO time frame. The study also found that the analysed banks reported non-financial performance reflected by Maqasid Shariah measures. This finding indicates that Islamic banks are responding to the need of society to ease the burden of adverse financial impacts on customers. Therefore, this research implicates that various parties have played their role and continue to do so in mitigating the consequences of COVID-19. This role emphasises the value of achieving Maqasid Shariah to maintain societal wellbeing and in helping the country implement sustainable growth plans. Accordingly, this study can function as a guide and serve as a lesson to all parties in reducing the effect of the current pandemic and any other shocks, including natural disasters and the financial and economic outcomes of the recession.

Keywords: COVID-19, socio-economy, Islamic financial institutions, Maqasid Shariah 


\section{Introduction}

Political uncertainty and disease breakouts are among the incidents that cause an economic slowdown in a country. The COVID-19 outbreak is a pandemic that has hit countries around the globe. This pandemic is an infectious disease first detected in November 2019, having spread from Wuhan, Hubei province of China. In Malaysia, the first case of COVID-19 was detected on 24 January 2020. A steep increase in cases up to five times the sum compared to previous cases, which began on 15 March 2020, caused great concern should no action be taken. The rapid spread of the virus has urged the Malaysian government to implement the Movement Control Order (MCO) in the country. The first round of MCO lasted from 18 March 2020 until 31 March 2020, considering fourteen days of incubation of the COVID-19 period. Positive cases did not show a decline throughout the period, and the government again decided to reimplement the MCO for the second phase. The implementation of MCO is an action to prevent the transmission chain of the virus, especially to infected patients from unknown contacts. This transmission not only impacts the public health and its system but also on the national economy and community. For instance, society will likely experience lifestyle changes in spending, employment, education, and social life. MCO has restricted most business activities in the country except for essential services such as food suppliers and other basic needs.

The COVID-19 outbreak has had a worldwide effect due to the shutdown of businesses and factories, supply chains, and the tourism industry. The latter was disrupted due to restrictions enacted at international and domestic borders that impacted the trade and tourism sectors. A report published by the World Bank highlighted that Malaysia's economy would contract sharply by $3.1 \%$ in 2020 due to the pandemic, which hindered economic activities (World Bank, 2020). The restriction placed on business activities has resulted in increased unemployment due to employers' failure to pay workers' salaries, with a high rate of worker lay-off. Aware of the community difficulties, the government further permitted the Employees Provident Fund (EPF) withdrawal based on the funding available in the contributors' second account to support current expenses. Following that, the government released the Bantuan Prihatin Rakyat under the Economic Stimulate Package in February 2020 for the households to cover the cost of living during the COVID-19 outbreak. The package to sustain the majority of Malaysians during critical times resulted from the earlier announced MCO. Under the same package, the government issued the short-term economic recovery plan (PENJANA) for businesses affected by the pandemic.

Undoubtedly, all business sectors, individuals, or communities affected by the pandemic, with no exception to financial institutions, are also experiencing deterioration due to COVID-19. However, in order to ease the burden of the community, the banking institutions are required to release an automatic moratorium system. This moratorium offers customers a suspension of financing payments for six months. Understanding the difficulties of the affected groups such as households, borrowers, and businesses, BNM remains committed to assisting all borrowers after the moratorium ends. At the same time, BNM issued the Special Relief Fund financial facilities for SMEs affected by the pandemic. The government, individual, and corporate roles in supporting the affected groups due to the restriction placed to manage the 
outbreak have realised the achievement of Maqasid Shariah in preserving the community's rights and welfare.

Thus, this paper discusses the implication of COVID-19 on the socio-economic and Islamic banks by using content analysis tools to analyse the performance of the banks as signalled by the profit growth quarterly for the years 2019 and 2020. The following section concentrates on prior studies that discussed the impact of infectious diseases on the economy and socio-economy. It is followed by another section that explains the method of this study. The subsequent section presents the findings derived from data interpretation based on quarterly reports from banking institutions and a discussion of the roles of the government and financial institutions in the community during a pandemic. The study is concluded in the final section.

\section{Literature Review}

\subsection{The Impact of Serious Diseases on Economic Structure}

From an economic lens, a disease will affect the economy through medical or treatment costs. High mortality caused by the disease will also affect the economic system, production, and consumption factors (Shang et al., 2021). Many economists and academicians argued that the current outbreak would cause a short-term fiscal impact and long-term economic impact on the nation worldwide (Shang et al., 2021). The COVID-19 outbreak has required nearly all countries to implement movement restrictions or lockdowns that have resulted in the reduction in demand and supply (United Nations Industrial Development (UNIDO), 2020; Mustafa et al., 2021). This reduction in demand and supply has caused a recession within the economic system.

Similarly, in Malaysia, the implementation of MCO has contributed to a decline in demand due to lower spending (Rio-Chanona et al., 2020). During the outbreak, the organisations and businesses could not continue their daily operations, including manufacturing activities. Many people have lost their primary sources of income, especially business operators and those who are self-employed (Nga et al., 2021). Production firms are not immune to this outcome and have also experienced a plummet in business income.

At the initial economic rebound, Malaysian production and consumption appeared positive. However, the re-enforcement of the MCO in the middle of March 2020 saw a sizeable reduction in the second quarter of the year. During this period, many businesses witnessed a sizeable reduction in production caused by lower consumption, reduced revenue and profitability, and lower labour. It has subsequently caused the high unemployment rate. According to BNM (2020a), Malaysian economic activities continued to recover in April 2020 in line with the second phase of MCO. High-frequency indicators showed that the labour market, household spending, and trade activities improved (BNM, 2020a). However, the recovery rate was uneven between sectors, with economic activity in some of the remaining industries below pre-pandemic levels and increasing slower in the labour market. This outlook remains subject to risks, especially in lieu of the continuing uncertainty surrounding the current domestic and global pandemics (BNM, 2020b). 
Meanwhile, in the context of economic and finance in Malaysia, BNM (2020) reported on the first quarter of 2020 GDP growth at 0.7 per cent, compared to the first quarter of 2019 GDP growth at 4.5 per cent. These quarter results reflect the enforcement of MCO. Economic slowdown during the pandemic was directly caused by the disease and further indirectly affected by government-enacted regulation and preventive actions by the country's authority. Many studies have been conducted on the impact of inevitable pandemics on the economy. It was evident that diseases had an exceptionally infectious impact on the economy at the macro and micro levels. Events of infectious diseases affect the public health system and various economic sectors, including agriculture, food, trade and travel, and market and retail (Smith et al., 2019).

A study was conducted by Dimmock et al. (2016) on the impact of an outbreak on the events of the economic downturn in 1998. The zoonotic disease transmission from pork was discovered in Malaysia, and the virus which first emerged in the country was therefore referred to as Henipavirus, or Nipah Virus. Consequently, the Malaysian government had to pay approximately USD 97 million to prevent the outbreak transmission by killing about 1.1 million pigs. Beyond that, the government had to bore additional costs of approximately USD 563 million in lost tax revenues to the international trade and the costs for biosecurity and slaughter facilities for the control program. To socio-economic stature, the Nipah outbreak caused an estimated 36,000 people to lose their jobs in various industries (Bonaccorsi et al., 2020).

Due to international and domestic lockdowns, tourism is one more sector affected by a pandemic. The same scenario is observed with COVID-19. The restriction on country exit-entrance caused the traveller to be restricted from entering or exiting the affected country or countries. Another industry affected is hospitality. Hotels record drops in the number of guests and bookings as well as their revenues. It is brought to difficulties, as the industry needs to reduce several costs, including salary and employee reductions. Except for a few cases, the COVID-19 outbreak has necessitated many countries to restrict international travel. In the study conducted by Delivorias and Scholz (2020), the economic impact of the Middle East respiratory syndrome coronavirus (MERS-CoV) outbreak in 2015 on the Republic of Korea's tourism was associated with 2.1 million fewer non-citizen visitors, which corresponded to about USD 2.6 billion loss in tourism revenue.

Meanwhile, the global economic loss was near USD 40 billion due to SARS. According to the China Bureau of Statistics, China's loss in GDP at $0.8 \%$ in 2003 involved tourism, travel, hotel and restaurant, and retail industries (Smith et al., 2019). The COVID-19 outbreak is not the first outbreak that has caused an economic slowdown. Nevertheless, this global pandemic has caused a worldwide economic crisis. Country lockdowns and the enforcement of movement restrictions have delimited the economic activities in many sectors. Malaysia and many world countries have to experience this deadly infectious disease that has caused financial downturns everywhere.

\subsection{Socio-Economic Impact}

The global COVID-19 pandemic is beyond the public health issue with immense 
socio-economic consequences. The dependency on trade and international and domestic travel tends to cause economic shock waves. Hence, there is no doubt that households and businesses remain the largely affected groups due to COVID-19. According to United Nations (2020), approximately 60 to 70 per cent of households' income dropped, and household consumption also decreased during the outbreak. In this regard, a survey conducted on job and skill demand revealed that, since the beginning of the pandemic and the implementation of COVID-19-related containment measures, the volume of online job postings had decreased significantly (Organisation for Economic Co-operation and Development (OECD), 2021). A study conducted by Martin et al. (2020) on the socio-economic impacts of COVID-19 indicates that in simulations of a three-month lockdown, the poverty rate increases from $17.1 \%$ to $25.9 \%$ during the crisis in the Bay Area. Household savings and consumption drop significantly, and the average recovery time for individuals is almost one year. Post-crisis, the long recovery time will experience a further exacerbated general decrease in demand, people's change in consumer behaviour, and a general slowdown of economic activities (Martin et al., 2020).

The community has experienced the pandemic's impact in Malaysia, primarily those of lower-income households and self-employed. These groups are among the worst affected by MCO as they do not have a fixed income. Based on a survey conducted by the Department of Statistic (DOS) Malaysia (2020) involving 168,182 respondents, as of March 2020, only 5\% of the self-employed had enough savings to sustain a livelihood for three months, while $71 \%$ had only enough savings per month (Lim, 2020). The survey indicates that self-employed households will experience adverse shocks during a pandemic or other disasters that lead to an economic crisis. The other study conducted by Yong and Sia (2021) revealed that the COVID-19 pandemic has significant impacts on society's wellbeing in Malaysia, the most severe of which are adverse mental health and job unemployment.

The Conditional Movement Control Order (CMCO) was implemented after the number of positive daily cases reached a single-digit figure. Due to the sudden increase in cases, the government has taken steps to reimplement the MCO in some areas that have experienced a sharp increase. This action likely marks a warning to the country and Malaysians to remain vigilant and alert with the virus, potentially increasing the rate of new cases and mortality. It has become a concern to the people and the country regarding socio-economic welfare, further causing household incomes to remain immobile. At the same time, the moratorium period has expired and caused the community to experience continued hardship. Debtors may be troubled to resume payment as scheduled, and banks may be concerned for the same reason that they may increase arrears and require debt write-offs that can quickly turn into additional changes.

\subsection{The Impact of Pandemic on the IFIs}

The shutdown of economic activities due to MCO has dramatically affected the community. All activities were restricted during the period, and things stood at a standstill. As a result, employees were unable to work, and the households ran out of supply and are thus facing financial constraints. During the MCO, household spending fell sharply at the peak of MCO. 


\section{Macrothink}

Due to this, banks also recorded low transactions in receiving deposits and lower financing or loan disbursement, coupled with implementing the moratorium and other banking transactions that rely on it. Subsequently, the global economy is expected to experience an economic downturn and a prolonged recession, adversely affecting a financial institution's capital as its profitability and asset quality decline (Deloitte, 2020). The impairment of financing may cause dented assets quality or potential lower income due to softer loan growth, substantial net profit margin compression, and a Day-One modification loss (Maybank Islamic, 2020). Meanwhile, RAM Rating Services Bhd (RAM Ratings) stated that banks in Malaysia are likely to record loan growth below that of 2019's 3.9\% expansion in the year 2020 (Salim, 2020).

The analyst believes that the moratorium will test the banking institutions' resilience, affecting the liquidity and working capital to cover interest expenses, overheads, and borrowing activities (Ali, 2020). On the other hand, according to Associate Professor Dr Ahmed Razman, it is not an issue in bank sustainability as long as the bank can accommodate the reduction in profits due to this six-month moratorium. However, he added, the current economy does not cause losses to banks but will affect its profits (Latiff \& Hayin, 2020). According to a report, reliable underwriting standards of Malaysian banks, sufficient income, and capital buffers should help banks deal with the impact of the pandemic (Ali, 2020).

\section{Method}

This study uses content analysis as a data collection tool to analyse the performance of banks. The data in this study was gathered from related websites, news articles, and quarterly financial reports. The information was obtained from the annual reports of five Islamic banking institutions: Bank Islam Malaysia Berhad (BIMB), Bank Muamalat Malaysia Berhad (BMMB), Maybank Islamic, CIMB Islamic, and Public Bank. These banks were selected for this study as leading Islamic banks in Malaysia to demonstrate the impact of the COVID-19 outbreak on their business operations.

\section{Analysis and Discussion of the Finding}

\subsection{Financial Analysis on Islamic Banks}

Following are the profit analysis and percentage growth of the first quarter period, second-quarter period, and the half-year 2020 and 2019 periods. 
4.1.1 Quarterly Profit Growth Result

Table 1. Profit of the period first quarter, second quarter, and a half year of 2020 and 2019

\begin{tabular}{lllllll}
\hline Banks & $\begin{array}{l}\text { Q1 2020 } \\
\text { (MCO) }\end{array}$ & Q1 2019 & $\begin{array}{l}\text { Q2 2020 } \\
\text { (MCO) }\end{array}$ & Q2 2019 & $\begin{array}{l}\text { H.Y. } \\
\mathbf{2 0 2 0}\end{array}$ & $\begin{array}{l}\text { H.Y. } \\
\mathbf{2 0 1 9}\end{array}$ \\
\hline BIMB & 163,467 & 160,077 & $\begin{array}{l}120,787 \\
(25 \%)\end{array}$ & 161,781 & $\begin{array}{l}284,254 \\
(11 \%)\end{array}$ & 321,858 \\
& $2.1 \%$ & & 23,341 & 9,149 & 48,884 \\
BMMB & $(9,058)$ & 25,542 & $\begin{array}{l}18,208 \\
(21 \%)\end{array}$ & & $(81 \%)$ & \\
Maybank Islamic & 384,820 & \multirow{2}{*}{549,276} & 135,370 & 528,596 & 520,190 & $1,077,872$ \\
& $(30 \%)$ & & $(74 \%)$ & & $(51 \%)$ & \\
CIMB Islamic & 195,863 & 189,859 & 10,851 & 237,866 & 206,714 & 427,805 \\
& $3.1 \%$ & & $(95 \%)$ & & $(51 \%)$ & \\
Public Islamic & 134,001 & 123,144 & 21,057 & 107,452 & 155,058 & 230,596 \\
& $8.8 \%$ & & $(80 \%)$ & & $(32 \%)$ & \\
\hline
\end{tabular}

Note. $\mathrm{Q}=$ Quarter, H.Y = Half Year, BIMB = Bank Islam Malaysia Berhad, BMMB = Bank Muamalat Malaysia Berhad.

Table 1 presents an analysis based on the profits recorded for the first quarter period, second quarter, and a half year of 2019 and 2020. Based on the table above, the bank growth percentage showed that all the banks had negative growth in the second quarter resulting from the MCO, which was at the peak of the MCO period. The percentage of growth performance of Maybank Islamic at the first-quarter result showed a negative growth at -30 per cent between 2020 and 2019 compared to 117 per cent profit growth between 2019 and 2018 (see Table 2). The first quarter for Public Islamic Bank showed a positive growth between 2020 and 2019 but declined 0.8 per cent compared to between 2019 and 2018.

The profit growth performance for the first half-year, 2020 and 2019 showed that the percentage growth of the five banks was negative. However, BIMB was lowest at -11 per cent, followed by Public Islamic at -31 per cent, Maybank Islamic and CIMB Islamic at -51 per cent, and the highest negative growth for BMMB. 
Table 2. Profit of the period first quarter, second quarter, and a half year of 2019 and 2018

\begin{tabular}{lclllll}
\hline Banks & Q1 2019 & Q1 2018 & Q2 2019 & Q2 2018 & HY 2019 & HY 2018 \\
\hline BIMB & 160,077 & 147,707 & 161,781 & 138,193 & 321,858 & 285,900 \\
& $8.4 \%$ & & $17 \%$ & & $12.5 \%$ & \\
BMMB & 25,542 & 33,180 & 23,341 & 45,306 & 48,884 & 78,487 \\
& $(23 \%)$ & & $(48 \%)$ & & $(37 \%)$ & \\
Maybank & 549,276 & 252,627 & 528,896 & 490,365 & $1,077,872$ & 742,992 \\
Islamic & & & & & & \\
& $117 \%$ & & $7.9 \%$ & & $45 \%$ & \\
CIMB Islamic & 189,859 & \multirow{2}{*}{156,014} & 237,866 & 219,435 & 427,805 & 375,449 \\
& $21 \%$ & & $8.4 \%$ & & $13 \%$ & \\
Public Islamic & 123,144 & 112,348 & 107,452 & 120,566 & 230,596 & 232,914 \\
& $9.6 \%$ & & $(10 \%)$ & & $(0.9 \%)$ & \\
\hline
\end{tabular}

Note. $\mathrm{Q}=$ Quarter, H.Y = Half Year, BIMB = Bank Islam Malaysia Berhad, BMMB = Bank Muamalat Malaysia Berhad.

BMMB suffered losses in the first quarter of 2020, while the percentage of profit growth performance showed a very significant negative between the current quarter and the quarter of 2019. Similarly, BMMB also experienced negative growth in the percentage of profit growth performance between the 2019 and 2018 quarters. However, in 2019, BMMB still had a profit of RM25,542 billion, less 23 per cent compared to the first quarter year 2018. Thus, the percentage growth between the first quarter of 2019 and 2018 also decreased at -23 per cent.

\subsection{The Government's Response to the COVID-19 Impact}

COVID-19 has been more than a health crisis; it has substantially caused a worldwide economic crunch. According to the United Nations (2020), this pandemic affects health and the socio-economy. Since the pandemic, the government of Malaysia has aided the community by implementing a stimulus package. The economic stimulus package assists the households by receiving cash under the Bantuan Prihatin Nasional program. Moreover, the government has collaborated with BNM to provide an emergency relief scheme and other forms of assistance to ease the burden on the affected community.

Meanwhile, the affected businesses also received assistance under the short-term economic recovery plan. BNM has responded to the COVID-19's impact to assist the individual and businesses through a relief measure in the form of a six-month moratorium of financing repayment and the Special Relief Fund (SRF) designed to help reduce the short-term cash flow problems faced by Small and Medium Enterprises (SMEs) affected by the COVID-19 pandemic.

The implementation of the economic stimulus package matches Mr Firas Raad, a World Bank Group Representative to Malaysia and Country Manager in his statement, 
Social protection measures are needed to help vulnerable Malaysians survive the current economic storm and thrive in a new post-pandemic reality. Protecting livelihoods is essential so that those who have lost their jobs and businesses can get back on their feet and contribute to Malaysia's economic recovery.

The Economic Stimulus package covers all sectors and every social group, primarily for a household in receiving the benefits. The Bantuan Prihatin Rakyat package relieves individuals and businesses facing temporary financial constraints from the COVID-19 pandemic (refer to Tables 3 and 4).

Table 3. Bantuan Prihatin Nasional Target Recipients

\begin{tabular}{lll}
\hline Eligible category & Amount & Recipients \\
\hline Households earning RM4,000 and below & RM1,600 & Up to 4 million households \\
Households earning RM4,001 - RM8,000 & RM1,000 & Up to 1.1 million households \\
Single individuals aged 21 years and above earning & RM800 & Up to 3 million individuals \\
RM2,000 and below & & Up to 3 million individuals \\
Single individuals aged 21 years and above earning & RM800 & \\
RM2,001 to RM4,000 & & \\
\hline
\end{tabular}

Under the second Malaysian Economic Stimulus Package, the Malaysian government announced one-off cash aids to households earning RM8,000 and below and individuals earning RM4,000 and below. 
Table 4. Malaysian Economic Stimulus Package 2020

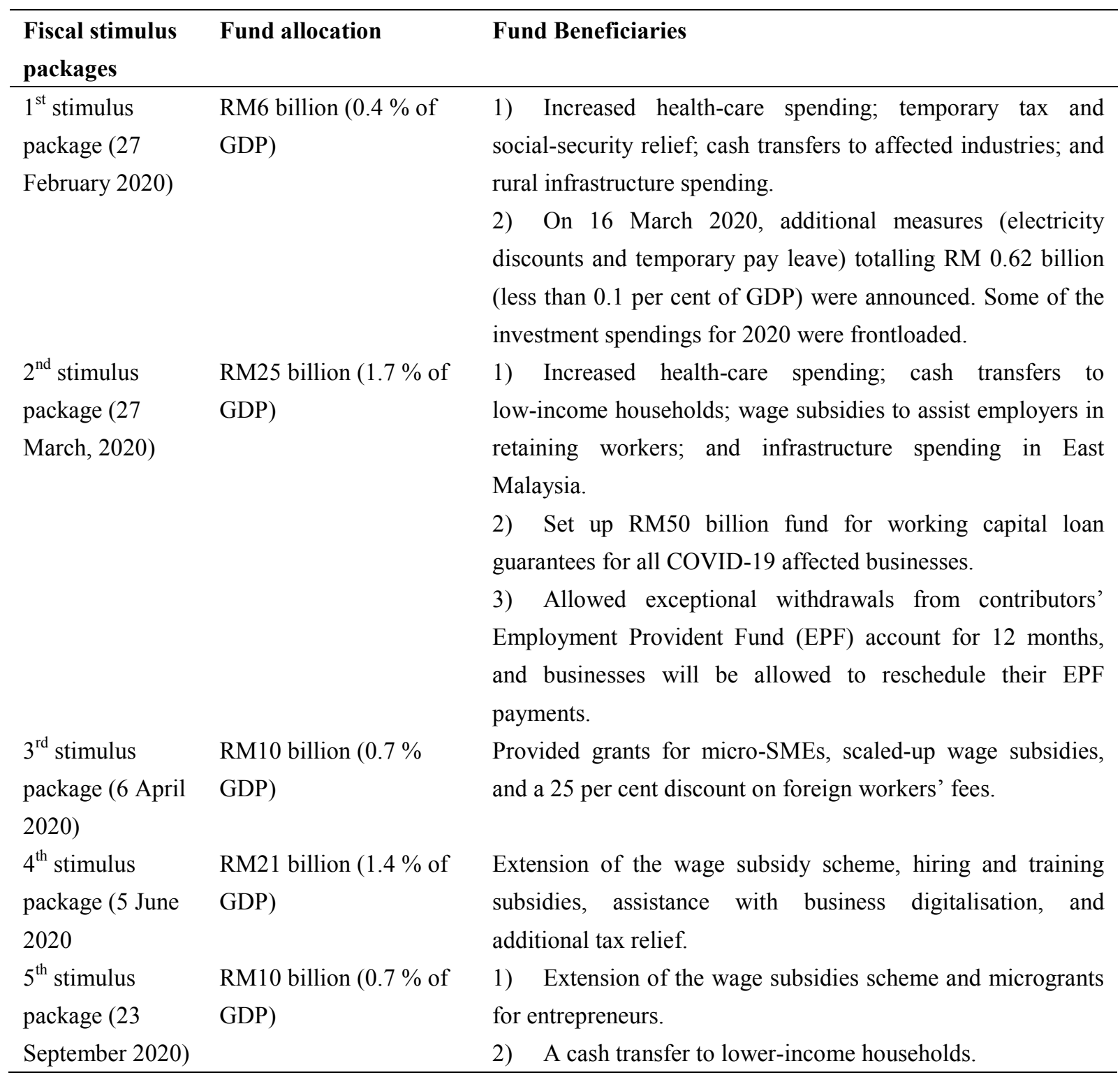

Source: International Monetary Fund, 2020.

The Malaysian government have announced five economic stimulus packages up to 23 September 2020. The packages cover aid and relief to households, businesses, and SMEs and wages subsidiary schemes and grants provided for entrepreneurs. The second and fifth Economic Stimulus Package announced one-off cash transfers for lower-income households.

\subsection{Malaysians Respond to the COVID-19}

Since implementing the MCO, the government and other parties, including individuals, corporations, and NGOs, have presented themselves in channelling numerous forms of aid regardless of religion or ethnicity. Various types of assistance were extended to the frontline workers, hospitals, and the community to reduce the strain caused by the MCO during to COVID-19 outbreak in Malaysia. Implementing the MCO to curb the onset of the pandemic 
was a critical period for the community, especially households, self-employed individuals, and businesses, especially those which are small-scale.

Through the CSR programs, financial institutions as corporate organisations voluntarily provided and distributed aids for the community, frontlines, and hospitals such as food supply, medical suites, or other equipment for hospital use. The community and NGOs' concern for the frontliners working hard to prevent the pandemic was manifested through contributions as tokens of gratitude and injecting enthusiasm in providing services.

The enforcement of the MCO was felt by many individuals, particularly students who were stranded in their respective colleges and universities. The respected universities and other agencies, including NGOs and individuals, came forward to supply food and other necessities for this group. Although many people extended assistance at this critical time, the fact is that such assistance has become commonplace to the individuals and NGOs involved. Apart from the locals being the focus of assistance, non-citizens such as Rohingyas also received the help of raw materials and other essential food ingredients during the MCO (Ghazali, 2020). Similarly, the homeless received extended aid during this period.

Besides that, corporate bodies were lending a hand through the crowdfunding platform. For instance, Bank Muamalat launched the Shariah Fund to cooperate with Non-Governmental Organisations (NGOs) as a charity partner. BMMB allocated a fund of forty thousand Malaysia Ringgit to selected recipients through six communities-based projects involving education, health, and economic empowerment during the first phase. Following the phase, fifteen projects will continue to be implemented (Bernama, 2020a).

Countless parties have provided various assistance in responding to the impact of COVID-19 and continue to do so. This pandemic has cultivated the values and a sense of responsibility towards the community in need. The spirit of cooperation and service practised by the Malaysian community has bridged the poverty gap in helping the needy. To learn from this crisis, Muslims are constantly reminded to prepare for the worse situation by helping the disadvantaged in times of difficulty.

\subsection{Monetary Policy and the Measures to Address COVID-19's Impact}

In dealing with COVID-19, different parties have played their role in minimising the spread of the virus. Many individuals, NGOs, corporate organisations, and the government have assisted the affected groups under MCO. Prolonged MCO causes the household to experience a deficit, especially self-employed ones. Also, many individual communities face difficulties covering living costs and other debts such as banking-related debts. For instance, the debtor may find himself unable to repay bank loans and instalments. Various aids were introduced to assist the household, businesses, and other affected groups in responding to the crisis. Financial institutions, namely banking institutions, approved the policies issued by the central bank to ease the burden of the community.

The financial relief assistance is the facilities meant for the worst affected due to the COVID-19 outbreak. The banks are committed to assisting lenders by allowing an automatic six-month moratorium. The moratorium is one mechanism that allows the borrower to defer 


\section{Macrothink}

International Journal of Social Science Research

ISSN 2327-5510

2022, Vol. 10, No. 1

the loan's monthly instalment or financing. This assistance will ease the monthly burden of individuals and businesses whose income is affected by the pandemic. For the short term, the moratorium is an alternative to reduce expenses.

Nevertheless, the borrower is obligated to pay back as scheduled after the six-month period of the moratorium has expired. The moratorium ends in September, and the borrower households and businesses may have difficulties upholding the repayment as the economy is still in an unpredicted condition. Apart from an unstable economy, the daily cases of infection continue to record high numbers that have resulted in the reimplementation of MCO in a few states. Thus, banks are obliged to carry out added effective measures to address the impact of COVID-19.

\subsubsection{Debt Payment Alternative}

The automatic moratorium enables the debtor to defer the monthly instalment for six months without charges or penalties. However, this facility is only applicable for non-overdue financing accounts exceeding 90 days as of 1 April 2020.

The credit cardholder. The bank will automatically convert the outstanding balance into a three-year term loan with $13 \%$ per annum for individuals who cannot pay the minimum monthly payment. The interest rate at $13 \%$ per annum is lower than the usual rate of 15 to $18 \%$ p.a charges for unpaid credit balance. Also, the converted credit card to the loan is applicable to apply for the six-month deferment.

Rescheduling and restructuring aim to provide financial assistance to customers in need, such as individuals and businesses. Rescheduling or restructuring allows customers to make repayments at a lower rate and manage their cash flow. This facility allows continuity in their businesses and avoids legal action.

Furthermore, BNM (2020b) offers additional relief measures to assist affected SMEs, safeguard jobs, and support growth. These include increasing the allocation of the SRF from RM2 billion to RM5 billion and increasing the allocation of the All Economic Sectors (AES) facility from RM5.8 billion to RM6.8 billion. 


\subsection{Assistance and Relief Measures of Islamic Banks}

Table 5. Details of the assistance by Islamic Banks

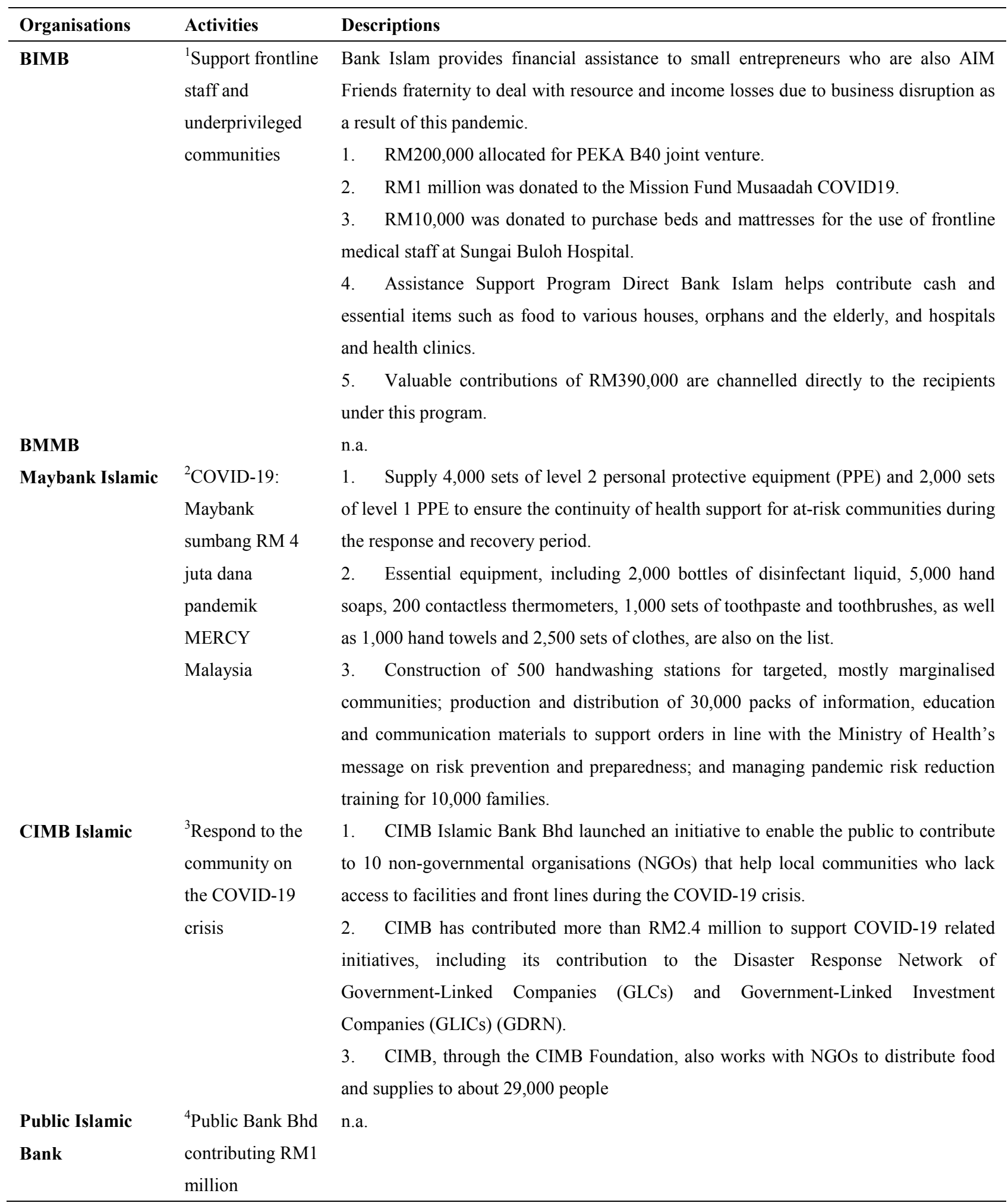

Sources: ${ }^{1}$ BIMB Holdings, 2020, ${ }^{2}$ Bernama, 2020b, ${ }^{3,4}$ Shankar, 2020. 


\subsection{The Achievement of Maqasid Shariah}

According to Al-Imam as-Syatibi, Maqasid Shariah describes the command of Allah in delivering goodness to universal human beings and protecting them from damage and harm. Maqasid Shariah is explained in three categories, namely, Dharuriyyat (necessities), Hajiyyat (convenience), and Tahsiniyyat (comfort). The category of Dharuriyyat is often highlighted as an essential element in human life. Failure to meet the necessities level can lead to the destruction of life in this world and the hereafter. The necessities include food, shelter, clothing, health, and safety. The necessities are explained in preserving the five elements in human life as a servant on earth: preserving the religion, preserving life, preserving intellect, preserving dignity, and preserving wealth.

Maqasid Shariah covers the welfare of society in various aspects of human life towards brotherhood, society and family, justice and safety, wealth and dignity, good governance, reduction of poverty and fulfilment of employment, economy, reduction of crime, and security and stability (JAKIM, 2015). Maqasid Shariah becomes the guidance for humans to ensure they are balanced to meet the needs and requirements of an individual life without leaving the other's right. From the Islamic economic perspective, it can be achieved by establishing the maslahah in the economic activities through justice and protecting the public's rights (Hurayra, 2015). In the socio-economics development, Maqasid Shariah is the basis for economic development, by supporting each other as a social responsibility concerning the other individual in a society to fulfil the community's needs, especially during the difficulties of survival. It is society's responsibility to support the groups affected by any disasters such as natural disasters, oppression, or the current COVID-19 pandemic. Lack of attention to the needy may create other social problems that burden society. In this challenging situation, the human is tempted to commit evil without the strong faith in his heart. For survival in life and to protect the faith of Muslims, it is a commitment for the government and community to channel assistance for the disadvantaged group.

Many people were severely affected by MCO's enforcement during the crisis. This restriction has led the community to difficulties by restricting economic activities. However, everyone is responsible for following the government's orders to prevent the virus from spreading. Maqasid Shariah explains the need to preserve individual life from harm, and Islam forbids its believers to place themselves in perdition. This pandemic is not only a disease and health issue but a factor that creates economic distress that affects socio-economic wellbeing. The community needs to bear the restriction on movement in fighting and to break the virus's transmission. The implementation of $\mathrm{MCO}$ has limited economic activity both during and after the period. Thus, creating a dynamic, effective, and healthy social system is critical to preserving a community's social system (JAKIM, 2015). For example, the community must work together to assist those in need during the pandemic in this critical situation.

\section{Conclusion}

The COVID-19 outbreak is beyond solely infectious disease. There is a need for the government and society to prevent, cure, and stop the virus transmission chain altogether. In dealing with it, prompt action from the government through the implementation of the MCO 
has resulted in the forced shut down of economic activities that finally affected the economic system. Many business activities were restricted due to the enforcement of MCO, which led to the economic slowdown, increased unemployment, and raised poverty levels in Malaysia and elsewhere. To ease the burden of the community, the Malaysian government announced the Bantuan Prihatin Nasional program in the form of cash and other economy-stimulated packages for the affected groups.

With the same intent, financial institutions in Malaysia responded to the monetary policy announcement of the measures to address the impact of COVID-19. The outbreak affected nearly all economic segments, and the banking institution is regarded as a significant sector in the country. Five Islamic banks were analysed to measure their performance during the pandemic in the study. The analysis found that the pandemic affected the banks by measuring their profit growths in quarters 1 and 2 of 2020 and 2019.

Noticeably, many parties also showed their concern towards the current situation. It has fostered a sense of shared responsibility towards society during a challenging time, as expressed by individuals, NGOs, and corporations such as banking institutions. The assistance channelled by the society to the society has realised the Maqasid Shariah in safeguarding the interests of the ummah. The level of necessity explained the protection of the five principles in human life, which are religion, life, intellect, dignity, and wealth.

Malaysia again experienced the third wave of COVID-19, resulting in higher daily cases. The government is reluctant to implement the MCO at this stage due to its enormous socio-economic impact. Given the number of daily cases and economic effects, the tourism industry and other businesses are concerned about the reimplementation of the movement restriction. Even though Malaysia has begun to recover from the socio-economic downturn resulting from the pandemic in the recovery movement order (RMCO) stage, many still see and feel the effects. According to the Ministry of Health of Malaysia, there is no way to stop the transmission chain of the virus unless all people are responsible for observing and committed to practising the ways to curb the transmission rate. These include practising social distancing, wearing masks, and healthy hygiene practices. It is a challenge for the country to break the chain of infection since certain groups in the society are unwilling to abandon the culture of handshaking or gathering, and the level of awareness is still low against the new norm. Should the country find itself unable to contain the virus in the same way as it did before, in such a scenario, the current pandemic may continue to spread, and Malaysia may continue to face economic uncertainty. The possibility is Malaysia's economy contracting sharply, increasing unemployment and leading to poverty. Therefore, further studies should be conducted by measuring the banking sector's performance during the recovery period and discussing the socio-economic situation post-COVID-19 crisis.

\section{Acknowledgements}

First and foremost, praise God, the Almighty, for His blessings throughout this research work. Sincere gratitude to the Graduate School of Muamalat (GSM), Faculty of Economics and Muamalat and Universiti Sains Islam Malaysia for their expressed encouragement to this research 


\section{References}

Ali, S. P. S. (2020, May 11th). Bank tempatan hadapi kekangan, namun di kedudukan kukuh untuk pulih. Bernama. Retrieved from https://www.bernama.com/bm/am/news_covid-19.php?id=1840391

Bernama. (2020a, 22 September). Bank Muamalat launches social welfare crowdfunding platform. Malay Mail. Retrieved from https://www.malaymail.com/news/money/2020/09/22/bank-muamalat-launches-social-welfar e-crowdfunding-platform/1905608

Bernama. (2020b, Mar. 23rd). Covid-19: Maybank sumbang RM4 juta dana pandemik MERCY Malaysia. BH Online. B https://www.bharian.com.my/berita/nasional/2020/03/668388/covid-19maybank-sumbang-rm4-juta-dana-pandemik-mercy-malaysia

BIMB Holdings. (2020). Menangani Kesan Pandemik COVID-19: Mengekalkan Kesejahteraan Pihak Berkepentingan. Retrieved from https://www.bimbholdings.com/sites/default/files/menangani_kesan_pandemik_covid-19_me ngekalkan_kesejahteraan_pihak_berkepentingan.pdf

BNM. (2020a). Press Release: Monetary Policy Statement. Retrieved from https://www.bnm.gov.my/index.php?ch=en_press\&pg=en_press\&ac=5110\&lang=en

BNM. (2020b). Press Release: Additional Measures to Further Support SMEs and Individuals Affected by the COVID-19 Outbreak. Retrieved from https://www.bnm.gov.my/index.php?ch=en_press\&pg=en_press\&ac=5022\&lang=en

Bonaccorsi, G., Pierri, F., Cinelli, M., Flori, A., Galeazzi, A., Porcelli, F., ... Pammolli, F. (2020). Economic and social consequences of human mobility restrictions under COVID-19. PNAS, 117(27), 15530-15535. https://doi.org/10.1073/pnas.2007658117

Delivorias, A., \& Scholz, N. (2020). Economic Impact of Epidemics and Pandemics. European Parliamentary Research Service.

Deloitte. (2020). COVID-19: Impact on Financial Institutions and How to Respond. Retrieved from https://www2.deloitte.com/content/dam/Deloitte/my/Documents/risk/my-risk-covid-19-impac t-my-financial-institutions.pdf

Department of Statistics (DOS) Malaysia. (2020). Special Survey on the Effects of COVID-19 on the Economy and Individuals (Round 1). Retrieved from https://www.dosm.gov.my/v1/index.php?r=column/cone\&menu_id=a0dyT2d5U mFMNEZJVTlmL0k5cFJNZz09

Dimmock, N. J., Easton, A. J., \& Leppard, K. N. (2016). Introduction to Modern Virology (7th ed.). School of Life Sciences, University of Warwick: John Wiley \& Sons.

Ghazali, N. F. (2020, Apr. 26th). NGO bantu 650 keluarga Rohingya di Kelantan. Malaysia 
Kini. Retrieved from https://www.malaysiakini.com/news/522622

Hurayra, M. A. (2015). Achievement of maqasid al-shari'ah in Islamic banking: an evaluation of Islamic Bank Bangladesh Limited. Global Journal of Computer Science and Technology: A Hardware \& Computation, 15(1), 9-16.

International Monetary Fund (IMF). (2020). Policy Responses to COVID-19. Retrieved from https://www.imf.org/en/Topics/imf-and-covid19/Policy-Responses-to-COVID-19

JAKIM. (2015). Indeks Shariah Malaysia: Model Tadbir Urus Berteraskan Maqasid Shariah. Retrieved from http://www.islam.gov.my/images/ePenerbitan/pengenalan_ism.pdf

Latiff, A. R. A., \& Hayin, N. A. M. (2020). Untung bank terjejas tapi tak rugi. Harian Metro. Retrieved from https://www.hmetro.com.my/utama/2020/07/596685/untung-bank-terjejas-tapi-tak-rugi

Lim, L. L. (2020). The Socio-Economic Impacts of COVID-19 in Malaysia: Policy Review and Guidance for Protecting the Most Vulnerable and Supporting Enterprises. International Labor Organization.

Martin, A., Markhvida, M., Hallegatte, S., \& Walsh, B. (2020). Socio-economic impacts of COVID-19 on household consumption and poverty. Economics of Disasters and Climate Change, 4, 453-479. https://doi.org/10.1007/s41885-020-00070-3

Maybank Islamic. (2020). Condensed Financial Statement Unaudited income Statement for Financial Half Year Ended 30 June 2020 (vol. 85, pp. 1-55).

Mustafa, A. H., Zainal Abidin, N. B., Ahmad, N., \& Ogundare, E. A. (2021). Influence of COVID-19's active cases on Malaysia's key economic performance indicators. Journal of Emerging Economies \& Islamic Research, 9(1), 68-87. https://doi.org/10.24191/jeeir.v9i1.12736

Nga, J., Ramlan, W. J., \& Naim, S. (2021). Covid-19 Pandemic and Unemployment in Malaysia: A Case Study from Sabah. Cosmopolitan Civil Societies: An Interdisciplinary Journal, 13(2). https://doi.org/10.5130/ccs.v13.i2.7591

OECD. (2021). An assessment of the impact of COVID-19 on job and skills demand using online job vacancy data. Retrieved from https://www.oecd.org/coronavirus/policy-responses/an-assessment-of-the-impact-of-covid-19 -on-job-and-skills-demand-using-online-job-vacancy-data-20fff09e/

Rio-Chanonar, R. M., Mealy, P., Pichler, A., Lafond, F., \& Farmer, J. D. (2020). Supply and demand shocks in the COVID-19 pandemic: an industry and occupation perspective. Oxford Review of Economic Policy, 36(1), S94-S137, https://doi.org/10.1093/oxrep/graa033

Salim, S. (2020, 6 March). RAM: Slower loan growth seen for banking sector in 2020. The Edge Markets. Retrieved from https://www.theedgemarkets.com/article/ram-slower-loan-growth-seen-banking-sector-2020 $\% \mathrm{C} 2 \% \mathrm{~A} 0$. 


\section{Macrothink}

International Journal of Social Science Research

ISSN 2327-5510 2022, Vol. 10, No. 1

Shang, Y., Li, H., \& Zhang, R. (2021). Effects of Pandemic Outbreak on Economies: Evidence from Business History Context. Front. Public Health, 9, 632043. https://doi.org/10.3389/fpubh.2021.632043

Shankar, A. C. (2020, 26 March). 11 member banks of ABM donate RM10m to fight Covid-19. The Edge Markets. Retrieved from https://www.theedgemarkets.com/article/11-member-banks-abm-donate-rm10m-fight-covid1 9.

Smith, K. M., Machalaba, C. C., Seifman, R., Feferholtz, Y., \& Karesh, W. B. (2019). Infectious disease and economics: the case for considering multi-sectoral impacts. One Health, 7(100080), 1-6. https://doi.org/10.1016/j.onehlt.2018.100080

United Nations. (2020, 24 June). Malaysia's economy Expected to Contract Sharply due to COVID-19 in 2020. Retrieved from https://www.undp.org/content/undp/en/home/coronavirus/socio-economic-impact-of-covid-1 9.html

World Bank. (2020). Growth to Rebound in 2021. Retrieved from https://www.imf.org/external/pubs/ft/fandd/2018/06/economic-risks-and-impacts-of-epidemic s/bloom.pdf

Yong, S. S., \& Sia, J. K. M. (2021). COVID-19 and social wellbeing in Malaysia: A case study. Current Psychology. https://doi.org/10.1007/s12144-021-02290-6

\section{Copyrights}

Copyright for this article is retained by the author(s), with first publication rights granted to the journal.

This is an open-access article distributed under the terms and conditions of the Creative Commons Attribution license (http://creativecommons.org/licenses/by/4.0/). 